УДК 546.719:54.024:577.1

I. В. Леус, О. Д. Скорик, Н. В. Безцінна, Н. І. Штеменко

Дніпропетровський національний університет ім. Олеся Гончара

\title{
ВПЛИВ СТРУКТУРИ ЛІГАНДУ НА ПРОТИПУХЛИННІ \\ ТА АНТИОКСИДАНТНІ ВЛАСТИВОСТІ КЛАСТЕРНИХ СПОЛУК РЕНІЮ
}

Досліджено протипухлинну активність системи реній-платину, що містить цисдикарбоксилати ренію (III) із різними алкільними лігандами, кількість еритроцитів крові, їх морфологічний склад, еритроцитарну стійкість, концентрацію гемоглобіну крові, активність каталази, вміст ТБК-активних продуктів у плазмі крові щурів при розвитку карциноми Герена Т8 щурів. Показано, що система реній-платину має значний антиоксидантний ефект і пригнічус ріст пухлини, що с максимальним для сполуки 3 півалатним лігандом.

И. В. Леус, Е. Д. Скорик, Н. В. Безценная, Н. И. Штеменко

Днепропетровский нацииональный университет им. Олеся Гончара

\section{ВЛИЯНИЕ СТРУКТУРЫ ЛИГАНДА НА ПРОТИВООПУХОЛЕВЫЕ И АНТИОКСИДАНТНЫЕ СВОЙСТВА КЛАСТЕРНЫХ СОЕДИНЕНИЙ РЕНИЯ}

Исследованы противоопухлевая активность системы рений-платина, которая содержит цисдикарбоксилаты рения (III) с разными алкильными лигандами, количество эритроцитов крови, их морфологический состав, эритроцитарная стойкость, концентрация гемоглобина в крови, активность каталазы, концентрация ТБК-активных продуктов плазмы крови крыс при развитии карциномы Герена Т8 крыс. Показано, что система рений-платина имеет значительный антиоксидантный эффект и угнетает рост опухоли, что является максимальным для соединения с пивалатным лигандом.

I. V. Leus, E. D. Skorik, N. V. Beztsinna, N. I. Shtemenko

Oles' Gonchar Dnipropetrovs 'k National University

\section{INFLUENCE OF LIGAND STRUCTURE ON ANTICANCER AND ANTIOXIDANT PROPERTIES OF RHENIUM CLUSTER COMPOUNDS}

Under the model growth of T8 Guerin's carcinoma in rats we studied the anticancer activity of the system rhenium-platinum, which includes cis-dicarboxylates of rhenium (III) with different alkyl ligands, erythrocytes number and its morphological structure, erythrocytic stability, blood haemoglobin concentration, catalase activity and concentration of TBA-active products in the rats blood plasma. The reniumplatinum system had considerable antioxidat effect and prevented the growth of tumour, that was maximal for a compound with the pivalate ligand.

\section{Ветуп}

У наших попередніх працях [17] показано протипухлинні властивості кластерних сполук ренію різної конфігурації при введенні їх окремо та разом із 
цисплатином. Особливо ефективне пригнічення росту пухлини отримане при введенні цисплатину разом зі сполуками ренію, які вводили за схемою антиоксидантної терапії. Це дало нам можливість представити нову протипухлинну реній-платинову $(\mathrm{Re}-\mathrm{Pt})$ систему [14]. Посилення дії цисплатину та протипухлинні властивості сполук ренію можна пояснити перш за все наявністю у їх складі почверного зв'язку метал-метал між двома атомами ренію та здатністю цього зв'язку виявляти функцію пастки для радикалів. Проте коригувальні показники сполук стосовно системи еритрону відрізнялися у сполук ренію з різними лігандами, що вже свідчило про їх певний внесок у загальну біологічну активність досліджуваної системи. Вважаємо, що хімічна природа, гідрофобність лігандів та їх просторове розміщення навколо почверного зв'язку реній-реній можуть відігравати певну роль як у протипухлинній активності, так і у антианемічній, антиоксидантній активності сполуки поряд із наявністю почверного зв'язку, що робить актуальним подальший пошук біологічно активних сполук ренію. Нашу увагу привернули три сполуки цис-дикарбоксилатного класу 3 пропіонатними, півалатними та адамантанкарбоновими лігандами.

Мета роботи - оцінити протипухлинну активність цих сполук у системі ренійплатину в моделі пухлинного росту та визначити їх антиоксидантні та антигемолітичні властивості у цій моделі.

\section{Матеріал і методи досліджень}

Дослідження проводили на щурах лінії Вістар масою 100-150 г віком два місяці. Суспензія клітин карциноми Герена Т8 (30 \% перещеплювалася здоровим щурам від пухлиноносіїв, отриманих у Інституті онкології та радіології ім. Р. О. Кавецького МОЗ України. Цисплатин і ліпосомні форми кластерних сполук ренію готували в Українському державному хіміко-технологічному університеті на кафедрі неорганічної хімії [11]. Досліджували такі кластерні сполуки ренію 3 органічними лігандами (КРОЛ): $R e 2$ - цис-тетрахлороди-m-(1-адамантилкарбоксилато)диреній (III); Re4 - цис-діакватетра- $\mu$-хлородипропіонатодиреній (III) дихлорид; Re5 - цис-діакватетра- $\mu$-хлородипівалатодиреній (III) дихлорид (рис. 1).

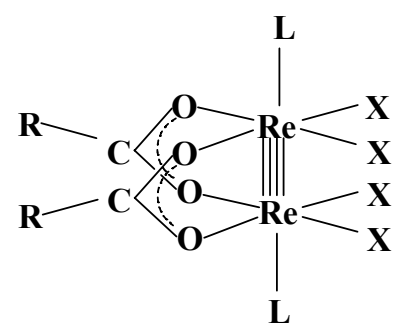

Рис. 1. Структурні формули досліджуваних сполук:

Re5: $R-C_{4} H_{7}, L-H_{2} O, X-C l ; R e 4: R-C_{2} H_{5}, L-H_{2} O, X-C l ; R e 2: R-A d C O O, L-H_{2} O, X-C l$

Цисплатин (cisPt) вводили одноразово у дозі 8 мг/кг на 9-ту добу після перещеплення пухлини. Сполуки ренію вводили за схемою антиоксидантної терапії [17], починаючи 3 третьої доби після перещеплення пухлини з інтервалом в 1 добу у кількості 3,4 ммоль/кг. На 21-шу добу тварин декапітували з використанням анестезії хлороформом, видаляли та зважували пухлину, досліджували вміст ТБК-активних продуктів у плазмі крові за С. Чевари [8], мазки крові виготовляли за I. А. Бичковим [11], визначення гемоглобіну проводили гемоглобінціанідним методом з ацетонціангідрином за А. М. Горячковським [4], активність каталази визначали за С. Чевари [8]. Метод кислотного гемолізу та метод побудови гемолітичних еритрограм проводили за 
схемою, запропонованою I. І. Гітельзоном [2]. Дослідні тварини поділені на групи по 7 щурів у кожній. Результати обробляли статистично 3 використанням $t$-критерію Стьюдента. Зміни показників вважали достовірними при $p<0,05$.

\section{Результати та їх обговорення}

Вибрана модель пухлинного росту (карцинома Герена Т8) інтенсивно розвивається та на 21-шу добу після імплантації ракових клітин досягає ваги 40-85 г, що складає 20-40\% ваги тварини. Згідно 3 отриманими даними пригнічення пухлинного росту, викликане цисплатином, найінтенсивніше проявлялось у період із 7-ї по 11-ту добу. Далі, з 12-ї по 19-ту добу пухлина знов починає збільшуватись у розмірах, цей процес трохи послаблюється на 20-21-шу добу. Наприкінці періоду спостереження об'єм пухлини становив трохи більше 3000 мм³ $^{3}$ (рис. 2). На відміну від цисплатину, ефект від комплексної дії сполук починає виявлятися на 13-ту добу й активне зменшення об'єму пухлини триває до кінця експерименту, на 21-шу добу пухлина майже зникає (рис. 2). Такі відмінності, можливо, вказують на інші механізми протипухлинної дії, які виникають завдяки сполукам ренію. При цьому спостерігається сильніший, стабільний ефект. Цисплатин - досить токсична сполука, яка впливає на фізичний стан тварин. У групі, де вводили лише цисплатин, смертність досягала $25 \%$; у групі, де сполуки діяли разом, смертність щурів становила 3-5 \%.

Цисплатин і комплекси ренію 3 адамантанкарбоновими лігандами $(\operatorname{Re} 2)$ призводили до значної редукції пухлини. У період з 14-ї по 17-ту добу відмічається швидке зменшення пухлини. Така регресія триває до 21-ї доби включно. Розміри пухлини не досягають $100 \mathrm{~mm}^{3}$. Цікаво, що смертність щурів у цій групі становила 20 30 \% [17]. Отже, комбінаційна дія $R e 2$ і цисплатину призводить до зменшення об'єму карциноми Герена приблизно у 30 разів на 21-шу добу порівняно 3 індивідуальним впливом одного цисплатину.

Динаміка пухлинного розвитку дещо відрізнялася при введені цисплатину разом зі сполуками ренію $з$ пропіонатним і півалатним лігандами (рис. 2). Пухлина трохи збільшувалась тільки до 11-ї доби, а потім ішла її регресія. У багатьох піддослідних тварин пухлину не виявили на 21-шу добу.

Отже, в усіх випадках застосування сполук ренію та цисплатину спостерігається більший протипухлинний ефект порівняно з одноразовим уведенням цисплатину.

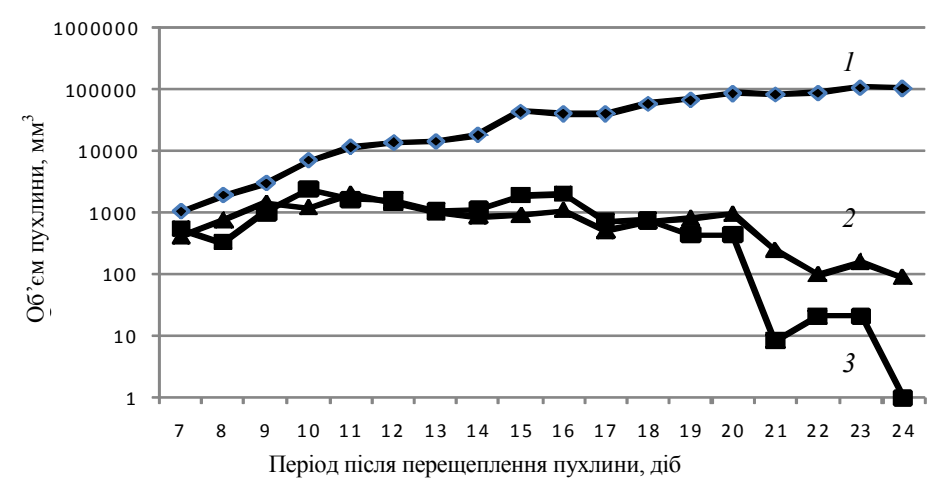

Рис. 2. Динаміка росту карциноми Герена під впливом цисплатину та при введенні протипухлинних систем сіsPt (1), $\operatorname{Re} 5+\operatorname{cisPt}(2)$ та $\operatorname{Re} 4+\operatorname{cisPt}(3)$

За дії цисплатину вага пухлини на 21-шу добу знижується у 5,3 раза порівняно 3 групою Т8 (табл. 1). Введення цисплатину разом зі сполуками ренію викликає значно 
сильніший ефект. У випадку введення Re5 + cisPt-системи вага пухлини зменшується у 40 разів порівняно з пухлиноносіями, вплив Re4 + cisPt-системи викликає редукцію карциноми у 16 разів порівняно з контролем та утричі порівняно з цисплатиновою групою. У результаті введення цисплатину разом із Re5 пухлина майже повністю зникає. Отже, півалатний ліганд у молекулі ренієвого компонента дає найсуттєвіший ефект у протираковій терапії. Концентрація гемоглобіну у групах, де тварини піддавалися хіміотерапевтичним заходам, підвищувалась порівняно з групою щурів із карциномою Т8.

Вага видалених пухлин і концентрація гемоглобіну

Таблиия 1 у крові щурів на 21-шу добу після інокуляції пухлинних клітин

\begin{tabular}{|l|c|c|}
\hline \multicolumn{1}{|c|}{ Група } & Вага, $~$ & Hb, г/л \\
\hline T8 & $63,27 \pm 15,19$ & $89,86 \pm 10,36$ \\
\hline $\operatorname{cisPt}$ & $11,88 \pm 4,90^{*}$ & $129,49 \pm 12,43^{*}$ \\
\hline $\operatorname{Re} 4+\operatorname{cisPt}$ & $1,497 \pm 0,34 *, * *$ & $119,67 \pm 5,98$ \\
\hline $\operatorname{Re} 5+\operatorname{cisPt}$ & $0,06 \pm 0,001^{*}, * *$ & $100,64 \pm 5,03$ \\
\hline $\operatorname{Re} 2+\operatorname{cisPt}$ & $3,92 \pm 2,55 * * *$ & $95,75 \pm 9,04 * *$ \\
\hline
\end{tabular}

Примітки: * - достовірна різниця порівняно з групою Т8, $p<0,05$; ** - достовірна різниця порівняно з цисплатиновою групою, $p<0,05$.

Цисплатин - одна 3 найефективніших хіміотерапевтичних сполук у клінічній практиці, однак у 10-40\% пацієнтів трапляється гостра анемія, що, можливо, є наслідком зниження продукції еритропоетину через ураження нирок i розвитку безпосереднього токсичного ефекту на кістковий мозок $[11 ; 17]$. Проте у нашому досліді не спостерігається досить значного зниження концентрації гемоглобіну та гематокриту. Причина цього у багатофакторній дії цисплатину, зокрема на нирки; внаслідок цього тварини втрачали багато рідини (спостерігалась діарея та поліурія) та різко знижувалась вага їх тіла. Подібні результати ми отримали, коли вводили здоровим щурам цисплатин: рівень гемоглобіну дорівнював 168,2 г/л. У цьому випадку також через поліурію та діарею організм утрачав багато рідини, що і викликало незначне підвищення концентрації гемоглобіну.

У групі, де цисплатин вводили разом із $R e 2$, концентрація гемоглобіну незначно перевищує досліджений показник у щурів групи Т8. Комплексна терапія цисплатином разом із Re4 та Re5 викликає незначне підвищення концентрації гемоглобіну порівняно 3 Re2. Але ці зміни досить незначні.

Морфологічні форми еритроцитів за дії цисплатину та комплексів ренію наведені у таблиці 2. Кількість морфологічних форм еритроцитів і їх зміна дає підставу говорити про ефективність тісї чи іншої сполуки у порівняльному плані.

Відомо, що будь-які зміни в організмі людини та тварин знаходять своє відображення в якісному складі та кількісному співвідношенні клітин крові. При розвитку пухлини та антиканцерогенній терапії зміни кількості еритроцитів спостерігалися лише при введенні цисплатину окремо та разом із Re2, а саме спостерігалося зниження кількості еритроцитів порівняно $з$ нормою.

В умовах розвитку пухлини спостерігається істотне зростання неоднорідності популяції еритроцитів. Морфологічна картина крові для цисплатинової групи характеризується підвищенням кількості дискоцитів (у 5,5 раза порівняно 3 пухлиноносіями), що, однак, на 30 \% менше за нормальні значення. Відсотковий вміст ехіноцитів наближається до норми, а кількість патологічних форм еритроцитів у 2,5 раза більший порівняно 3 контрольною групою. При лікуванні Re-Pt-системою 
картина крові майже в усіх групах близька до норми. При терапії цисплатином разом із Re4 та Re5 у щурів відбувається значне підвищення кількості дискоцитів, при використанні Re4 + cisPt-системи кількість ехіноцитів наближається до норми, а у випадку використання терапії цисплатином разом із $R e 5$ рівень ехіноцитів був нижчим за норму приблизно учетверо. Після введення Re5 + cisPt-системи фіксувався значний рівень патологічних форм еритроцитів, а присутність тілець Гейнца-Ерліха в невеликих кількостях може бути ознакою тяжких токсичних уражень різними речовинами. Комплексна терапія мала вплив також і на стійкість еритроцитів до кислотного гемолізу (рис. 3).

Табличя 2

Морфологічні форми еритроцитів крові тварин на 21-шу добу після інокуляції пухлинних клітин

\begin{tabular}{|l|c|c|c|c|}
\hline \multicolumn{1}{|c|}{ Група } & Дискоцити, \% & Ехіноцити, \% & $\begin{array}{c}\text { Патологічні форми } \\
\text { еритроцитів, \% }\end{array}$ & $\begin{array}{c}\text { Кількість } \\
\text { еритроцитів, } 10^{12} / \text { л }\end{array}$ \\
\hline Контроль & $65,00 \pm 6,12$ & $23,30 \pm 3,12$ & $11,70 \pm 2,16$ & $6,71 \pm 1,60$ \\
\hline $\mathrm{T} 8$ & $8,47 \pm 1,88^{*}$ & $52,57 \pm 3,66^{*}$ & $58,96 \pm 4,54^{*}$ & $4,51 \pm 1,93^{*}$ \\
\hline $\mathrm{CisPt}$ & $46,36 \pm 3,18^{*}$ & $24,99 \pm 3,84$ & $28,65 \pm 3,98^{*}$ & $4,03 \pm 0,55^{*}$ \\
\hline $\operatorname{Re} 4+\operatorname{cisPt}$ & $64,70 \pm 3,27$ & $21,60 \pm 1,08$ & $12,73 \pm 0,64$ & $6,15 \pm 1,12$ \\
\hline $\operatorname{Re} 5+\operatorname{cisPt}$ & $52,20 \pm 2,61^{*}$ & $5,61 \pm 0,36^{*}$ & $40,20 \pm 2,01^{*}$ & $6,64 \pm 1,04$ \\
\hline $\operatorname{Re} 2+\operatorname{cisPt}$ & $60,67 \pm 5,54$ & $30,18 \pm 4,08^{*}$ & $9,15 \pm 2,08$ & $5,05 \pm 0,91$ \\
\hline
\end{tabular}

Примітка: * - достовірно, порівняно з контрольною групою, $p<0,05$.

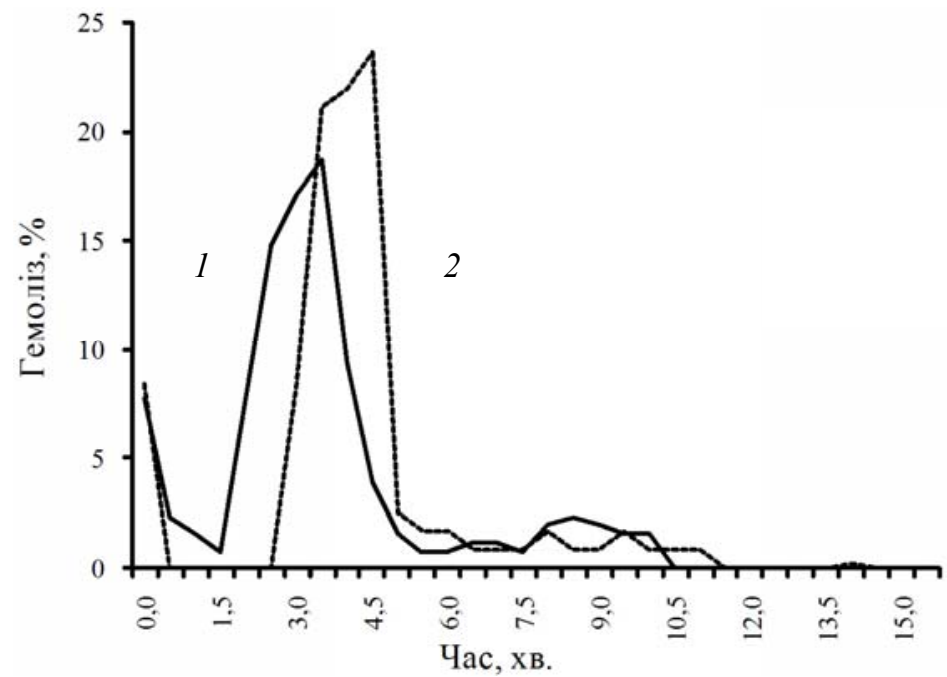

Рис. 3. Гемолітичні криві щурів із карциномою Герена під впливом протипухлинної системи $\operatorname{Re} 5+\operatorname{cisPt}(1)$ та $\operatorname{Re} 4+\operatorname{cisPt}(2)$

У нормі гемоліз триває приблизно 13-14 хвилин. Вивчення еритрограм щурів із карциномою Герена Т8 виявило низьку стійкість еритроцитів у цій групі. Час гемолізу зменшувався на 30 \%, підвищувався відсоток гемолізу майже удвічі, початок гемолізу пересувався на 1-2 хвилини, зменшувався інтервал стійкості [9].

Уведення тваринам цисплатину викликало суттєве зниження стійкості еритроцитарних мембран. Максимум гемолізу був навіть більший ніж у Т8, інтервал стійкості скорочувався вдвічі. Це свідчить про те, що цисплатин $є$ токсичним для червонокрівців, викликає порушення у їх структурі та анемію. 
За спільної дії КРОЛ і цисплатин сприяють зсуву максимуму гемолізу порівняно 3 T8, але період стійкості еритроцитів дещо скорочується порівняно 3 контролем. Тому цей вплив не можна вважати достатньо позитивним і слід звернути увагу на ліганди, які краще стабілізують мембрани червонокрівців. Така комбінація сполук підвищує еритроцитарну стійкість порівняно 3 цисплатиновою групою. Припускаємо, що завдяки органічним лігандам сполуки ренію здатні зв'язуватися 3 еритроцитарною мембраною [5; 12]. А почверний зв'язок, який $\epsilon$ пасткою для вільних радикалів, може запобігати руйнуванню мембрани еритроцита, викликаному порушенням окисно-відновного гомеостазу за рахунок онкотичних процесів і впливу прооксиданту цисплатину [7].

У групі, де щури з трансплантованою карциномою Герена не підлягали впливу будь-яких засобів, спостерігалося значне підвищення концентрації ТБК-активних продуктів (у 5,5 раза) (табл. 3), що свідчить про інтенсифікацію процесу перекисного окиснення ліпідів і виснаження системи антиоксидантного захисту. Це узгоджується із загальноприйнятою теорією оксидативного стресу при розвитку новоутворення.

Табличя 3

Активність каталази та концентрація ТБК-активних сполук після дії Re-Pt-системи

\begin{tabular}{|l|c|c|}
\hline \multicolumn{1}{|c|}{ Група } & Активність каталази, кат/л & $\begin{array}{c}\text { Концентрація ТБК-активних } \\
\text { продуктів, мкмоль/л }\end{array}$ \\
\hline Контроль & $10,79 \pm 0,54$ & $0,042 \pm 0,009 *, * *$ \\
\hline $\mathrm{T} 8$ & $10,37 \pm 0,49$ & $0,222 \pm 0,021^{* *}$ \\
\hline $\mathrm{CisPt}$ & $11,97 \pm 0,60$ & $0,116 \pm 0,010 *$ \\
\hline $\mathrm{CisPt}+\operatorname{Re} 4$ & $7,23 \pm 0,36^{*}, * *$ & $0,059 \pm 0,003 *, * *$ \\
\hline $\mathrm{CisPt}+\operatorname{Re} 5$ & $10,18 \pm 0,51$ & $0,068 \pm 0,002 *, * *$ \\
\hline $\mathrm{CisPt}+\operatorname{Re} 2$ & $11,17 \pm 0,56$ & $0,141 \pm 0,032^{*}$ \\
\hline
\end{tabular}

Примітки: див. табл. 1.

У літературі зустрічаються різні дані щодо глибини порушення окисно-відновного статусу організму у випадках розвитку новоутворення. Проте механізми, які відповідають за регулювання цих процесів, чутливі до ендо- та екзогенних факторів, тому можуть бути досить індивідуальними до конкретних умов і конкретного організму. При введенні протипухлинної системи Re-Pt ми виявили зниження рівня ТБК-активних продуктів [7]. Можна припустити, що самі по собі сполуки ренію володіють антиоксидантними та антирадикальними властивостями, однак вираженого антиканцерогенного ефекту при застосуванні їх у такій дозі за схемою антиоксидантної терапії не виявляють. Введення Re2 знижує рівень ТБК-активних (ТБК-тіобарбітурова кислота) продуктів лише на $21 \%$ порівняно з групою Т8. Проте він залишається утричі вищим за контрольну групу. Лікування Re4 та Re5 разом із цисплатином зменшує концентрацію продуктів перекисного окиснення ліпідів майже учетверо порівняно 3 групою пухлиноносіїв, і удвічі, якщо порівнювати з цисплатиновою групою, рівень ТБК-активних сполук був подібним до контрольної групи. Між цими групами достовірної різниці не виявлено. Можна припустити, що механізм дії $R e 2$ на інтенсивність пероксидного стресу дещо інший, зумовлений природою органічного ліганду.

У групі з уведенням цисплатину рівень ТБК-активних продуктів зменшується удвічі, але перевищує нормальний показник у 2,9 раза. Тобто зазначені сполуки дійсно виявляють антиоксидантні та антирадикальні ефекти in vivo, підтверджуючи досліди in vitro. Перш за все отримані результати можна пояснити протипухлинною дією Re-Pt-системи. Можливо, що як антиоксиданти Re4 та особливо Re5 найефективніші.

Гідрофобна природа лігандів, напевне, може сприяти транспортуванню ренієвих сполук та їх взаємодії з мембраною клітини. Реній - перехідний метал. Значення 
металів в онкотерапії та лікуванні інших захворювань дуже цікаве та перспективне. 3'ясовано, що вони можуть володіти антипроліферативною активністю, проте іншим аспектом їх дії виявляються токсичні ефекти $[6 ; 15]$. Відомий тісний взаємозв'язок металів із ферментами, активність яких вони здатні змінювати, взаємодіючи 3 їх активними центрами [1]. Можливо, що один із ключових об'єктів дії комплексів, які досліджуються нами в умовах канцерогенезу, - ферменти та деякі фактори, що беруть участь у процесі апоптозу. Активність ферменту можна вважати досить чутливим показником при вивчені впливу факторів ендо- та екзогенного походження, які викликають патології, пов'язані з порушенням окисно-відновної рівноваги організму. Але активність антиоксидантних ферментів не корелює з інтенсивністю перекисного окиснення ліпідів, що зазначено у попередніх дослідженнях [9].

У цьому модельному експерименті активність каталази суттєво не змінювалась (табл. 3). При введенні цисплатитну та $R e 2$ спостерігалося підвищення активності каталази, у середньому на 10 \% порівняно з інтактними пухлиноносіями та здоровими щурами. При введенні Re5 разом із цисплатином активність ферменту достовірно не змінювалась порівняно з першими двома групами. Слід звернути увагу на результати, отримані при введенні Re4 + cisPt-системи. У цій групі спостерігаємо достовірне зниження активності каталази (на 67 \%).

Усі три ренієві сполуки містять почверний зв'язок, але вони по-різному впливають на інтенсивність оксидативного стресу, викликаного розвитком новоутворення. Це частково може бути пов'язано зі зниженням продукції радикалів і регуляцією активності ферменту на рівні субстратів. Також можливий безпосередній вплив сполук ренію на активність каталази. Різниця в активності ферменту залежить від ліганду КРОЛ. Відомо, що кластерні сполуки ренію безпосередньо взаємодіють із білками, змінюючи характер взаємодії антиген-антитіло [13]. Також $є$ надруковані дані про зміну активності глюкозооксидази під впливом розчинів деяких сполук ренію. Механізм таких взаємодій вивчається. Отже, отримані дані про те, що зміна активності каталази у моделі пухлинного росту значно залежить від структури введеної сполуки ренію не може бути пояснена тільки регуляцією на рівні субстратів. Вплив Re4 на активність каталази потребує додаткових досліджень.

При введенні Re-Pt-системи спостерігався значно більший ефект, ніж під впливом лише цисплатину. Пухлина повністю зникала у 20-30 \% випадків спільного введення препаратів. При цьому поліпшувався і фізіологічний стан тварин. Рівень гемоглобіну зростав. Нормалізувалась морфологічна картина крові. Знижувався рівень продуктів перекисного окиснення ліпідів. Вірогідно, це можна пояснити захисними процесами протипухлинного росту, що активізуються в організмі уражених тварин. Тобто зазначені сполуки здатні до мобілізації захисних систем, таких як антиоксидантна, імунна, репараційна системи, процеси апоптотичної загибелі патологічних клітин тощо. Також у комплексі з біологічною активністю самих речовин вони здатні викликати деяке підвищення життєво важливих біохімічних показників крові. Цисплатин міститься в організмі в активній формі лише той проміжок часу, який необхідний для утворення комплексів із протеїнами; його дія визначається лише тією частиною, яка не зв'язана 3 білком. У групах, де вводили Re5 + cisPt-систему, ефект гальмування росту пухлини Т8 був більшим. Можливо, що завдяки своїй структурі сполуки ренію або самі здатні зв'язуватися $з$ цисплатином, при цьому зберігаючи його біологічну активність, або попереджувати його зв'язування з білком і тим самим його інактивацію. 


\section{Висновки}

Півалатний ліганд викликає найвираженіші ефекти системи Re-Pt (порівняно 3 пропіонатним і адамантанкарбоновим), оскільки він сприяє редукції пухлини у 40 разів. Для системи $\mathrm{Re}-\mathrm{Pt}$ iз півалатними радикалами навколо кластерного фрагмента характерні також найефективніші коригувальні властивості щодо системи еритрону, які полягають у зростанні концентрації гемоглобіну (на 28-71\%), підвищенні кількості дискоцитів (у сім разів), зниженні рівня ТБК-активних сполук (майже вчетверо).

\section{Бібліографічні посилання}

1. Барабой В. А. Металлотионеины: структура и механизмы действия / В. А. Барабой, Л. Г. Петрина // Укр. биохим. журн. - 2003. - Т. 75, № 4. - С. 28-35.

2. Болдырев А. А. Биомембранология: Учебное пособие / А. А. Болдырев, Е. И. Кяйвяряйнен, В. А. Илюха. - Петрозаводск : Изд-во КарНЦ РАН, 2006. - 226 с.

3. Бычков И. А. Морфологические особенности эритроцитов периферической крови в норме и патологии (световая микроскопия) // Гематология и трансфузиология. - 1991. - № 6. - С. 45-48.

4. Горячковский А. М. Пособие по клинической биохимии. - Одесса : ОКФА, 1994. - С. 126-128.

5. Изучение влияния комплексов рения с органическими лигандами на кислотную резистентность эритроцитов человека / Н. И. Штеменко, И. В. Пирожкова-Паталах, А. В. Штеменко и др. // Укр. биохим. журн. - 2000. - Т. 72, № 3. - С. 77-81.

6. Какарькін О. Я. Вплив антиоксидантів та фенобарбіталу на ферменти системи метаболічної активації у щурів // Experimental Oncology. - 2001. - Vol. 23. - P. 213-216.

7. Концентрація ТБК-активних продуктів у плазмі крові щурів при розвитку та гальмуванні росту карциноми Герена / М. М. Музиченко, О. Д. Жабицька, А. О. Тихомиров та ін. // Вісник Дніпропетр. ун-ту. Біологія. Екологія. - 2006. - Вип. 14, т. 2. - С. 117-121.

8. Чевари С. Определение антиоксидантных параметров крови и их диагностическое значение в пожилом возрасте / С. Чевари, Т. Андял, Я. Штренгер // Лаб. дело. - 1991. - № 10. - С. 9-13.

9. Investigation of antioxidant properties of the cluster rhenium compounds in the model of tumor growth / I. Leus, E. Zabitskaya, P. Collery et al. // Metal Ions in Biology and Medicine. - 2008. Vol. 10. - P. 399-402.

10. Liposomal forms of rhenium cluster compounds: enhancement of biological activity / N. I. Shtemenko, O. V. Berzenina, D. E. Yegorova et al. // Chemistry \& Biodiversity. - 2008. - N 5. - P. 1660-1667.

11. Prasad S. B. Cisplatin-mediated biochemical changes in mitochondria in tumor-bearing mice // Metal Ions in Biology and Medicine. - 2002. - Vol. 7. - P. 575-579.

12. Resistance of Guerin's carcinoma cells to cisplatine: biochemical and morphological aspects / O. V. Yurchenco, I. N. Todor, V. P. Tryndyak et al. // Experimental Oncology. - 2003. - Vol. 25. - P. 64-68.

13. Shtemenko N. I. Interaction of Rhenium cluster compounds with human blood proteins / N. I. Shtemenko, M. V. Gorelaya, L. M. Alexandrova // Metal Ions in Biology and Medicine. 2002. - Vol. 7. - P. 34-36.

14. Shtemenko N. I. Dihlorotetra $m$-isobutyratodirhenium (III): enhancement of cisplatin action and RBC-stabilizing properties / N. I. Shtemenko, P. Collery, A. V. Shtemenko // Anticancer Research. 2007. - Vol. 27. - P. 2487-2492.

15. Structural alterations of plasma membranes of Guerin's carcinoma cells upon the development of doxorubicine / V. F. Chekhun, O. I. Lebed, V. P. Tryndyak et al. // Experemental Oncology. 2002. - Vol. 24. - P. 279-283.

16. Supplementation by rhenium compounds instead of iron compounds during the treatment by erythropoeitin of anemia in cancer patients / P. Collery, N. Shtemenko, A. Shtemenko et al. // Metal Ions in Biology and Medicine. - 2004. - Vol. 8. - P. 534-537.

17. Synthesis, characterization, in vivo antitumor properties of the cluster rhenium compound with GABA ligands and its synergism with cisplatin / A. V. Shtemenko, P. Collery, N. I. Shtemenko et al. // Dalton Trans. - 2009. - Vol. 26. - P. 5132-5136. 